\title{
omsorgsmeldinger gir bedre og sikrere dokumentasjon
}

E-meldinger mellom spesialist- og kommunehelsetjenesten gjør informasjonsflyt og samhandling mer pålitelig og ef fektiv. Likevel tyr mange til telefonen for å kontrollere informasjonen.

\section{Forfattere}

Ida Slaatsveen

Sykepleier

Fakultet for medisin og helsevitenskap, Norges teknisk-naturvitenskaplige universitet

Ida Stavnesli

Sykepleier

Klinikk for lunge og arbeidsmedisin, St. Olavs hospital

\section{Janna Halsetrønning}

Sykepleier

Øya helsehus, Trondheim kommune

\section{Beate André}

Førsteamanuensis

Fakultet for medisin og helsevitenskap, Norges teknisk-naturvitenskapelige universitet

\section{Nøkkelord}
Kommunehelsetjeneste
Spesialisthelsetjeneste
Kommunikasjon
Dokumentasjon

Elektronisk omsorgsmelding

Sykepleien 2018 106(70599)(e-70599)

DOI: https://doi.org/10.4220/Sykepleiens.2018.70599 
Elektroniske omsorgsmeldinger er tatt i bruk for at dokumentasjonen og samhandlingen mellom spesialist- og kommunehelsetjenesten skal bli bedre og mer effektiv. Gjennom et helhetlig helse- og omsorgstilbud har kommunen fått mer kompetanse og flere midler, slik at pasienter kan skrives ut raskere fra sykehuset og bli tatt imot tidligere i kommunen. Dersom kommunen skal oppnå en optimal informasjonsflyt og ytterligere forbedret samhandling, må alle som er involvert i behandlingsløpet til den enkelte pasienten, sette seg godt inn i systemet med elektroniske omsorgsmeldinger. De må dessuten forstå hvilken informasjon den som overtar pasienten, har behov for.

Et av hovedmålene med elektronisk samhandling med omsorgsmeldinger (se faktaboks) er økt effektivisering og kvalitetsforbedring for å yte gode tjenester i hele pasientforløpet (1).

Denne artikkelen belyser derfor erfaringene med å bruke elektroniske omsorgsmeldinger til sykepleiere fra både spesialist- og kommunehelsetjenesten. Den belyser også hvorvidt denne bruken har bidratt til en mer effektiv og forbedret dokumentasjon og samhandling mellom spesialist- og kommunehelsetjenesten (1-3).

Studien vår er basert på et samarbeidsprosjekt mellom St.

Olavs hospital, Trondheim kommune og Institutt for samfunnsmedisin og sykepleie ved Norges teknisknaturvitenskapelige universitet.

\section{ELEKTRONISK MELDINGSUTVEKSLING}

Aktører i helse- og omsorgssektoren må forholde seg til ulike meldingstyper ved elektronisk meldingsutveksling. Basismeldinger er en gruppe meldingstyper som inneholder følgende: henvising, epikrise, laboratorie- og røntgenrekvisisjoner/svar.

Kilde: Norsk Helsenett

\section{OMSORGSMELDING}

Melding som skal sendes fra spesialisthelsetjenesten på utskrivningsdagen til kommunehelsetjenesten.

Meldingen skal inneholde informasjon om pasienter som følges opp av kommunens pleie- og omsorgstjeneste.

Kilde: Direktoratet for e-helse

\section{Metode}


Studien er basert på en intervju- og litteraturstudie. Vi samlet inn empiriske data gjennom semistrukturerte, individuelle intervjuer i mars 2017.

\section{Utvalg og informanter}

Vi rekrutterte og intervjuet totalt åtte sykepleiere. Fire sykepleiere var fra en avdeling ved et helsehus i Trondheim kommune, og fire sykepleiere var fra en avdeling på St. Olavs hospital. Begge kjønnene var representert. Alle sykepleierne hadde 75-100 prosent stilling og varierende fartstid som sykepleier.

\section{Intervju og analyse}

Individuelle, semistrukturerte intervjuer ble benyttet som metode (4, 5). I forkant av intervjuene utarbeidet vi en intervjuguide med fire konkrete spørsmål. Intervjuet ble gjennomført av førsteforfatteren og foregikk på avdelingen der sykepleierne jobbet (5).

Vi benyttet den tverrgående analysemetoden systematisk tekstkondensering for å analysere datamaterialet (6).

\section{Etiske overveielser}

Alle informantene mottok informasjon om prosjektet på forhånd. Deretter innhentet vi samtykke. Det var frivillig å delta, og de kunne når som helst trekke seg. Studien er godkjent av Trondheim kommune, St. Olavs hospital og Institutt for samfunnsmedisin og sykepleie ved NTNU. Dataene fra informantene er anonymisert, og svarene er blitt behandlet konfidensielt (5).

\section{Resultater}

Generelt viser funnene at alle sykepleierne syntes elektroniske omsorgsmeldinger var et godt hjelpemiddel. De bidro til bedre kommunikasjon. Samhandlingen ble mer effektiv og bedret dermed samarbeidet mellom helsetjenestenivåene.

\section{三 «Alle sykepleierne syntes elektroniske omsorgsmeldinger var et godt hjelpemiddel.»}

\section{Upålitelig informasjon}


Flere av informantene fortalte at informasjonen de fikk gjennom elektroniske omsorgsmeldinger, ikke alltid var godt nok utdypet, eller den manglet relevant og viktig informasjon. En informant sa følgende:

«Jeg synes noen ganger at informasjonen gjennom omsorgsmeldinger kan bli underkommunisert, det er lettere å forklare nærmere på telefon.»

Noen av informantene fortalte at de ikke alltid stolte på den informasjonen de mottok skriftlig, og følte det ikke var forsvarlig uten å ringe for å få bekreftet opplysningene. I likhet med funn fra andre studier (7) måtte sykepleierne i vår studie supplere med telefonsamtaler for å sikre tilstrekkelig informasjon om pasientens tilstand.

\section{«Det er ikke forsvarlig uten å ringe.»}

\section{Informant}

Dette behovet for å kontrollere informasjonen via telefon gjaldt spesielt medisinlisten i epikrisen, som noen ganger ikke stemte overens med medisinene som sto oppført på medisinkurven. En sykepleier i kommunen fortalte som følger:

«Jeg ringer alltid for å bekrefte at medisinene er riktige fordi jeg aldri kan stole på at det som står i epikrisen, er rett. Det er ikke forsvarlig uten å ringe.»

En sykepleier fra sykehuset sa derimot at de ikke lenger trengte å ringe om medisinlisten fordi slike opplysninger skulle sendes gjennom elektronisk melding.

Alle informantene fortalte at de brukte telefon når de trengte å få raskt svar på noe. Flere fortalte også at når man kommuniserer via telefon, må man svare med én gang. En informant sa at når man mottar en elektronisk melding, kan man velge å ikke åpne den eller kvittere for at meldingen er lest, og dermed utsette å forholde seg til meldingen. Man kan velge å lese meldingen senere, eller ikke lese den i det hele tatt. Dette utgjør en fare for at viktig informasjon ikke kommer frem i tide. 


\section{Foretok telefonkontroll}

Sykepleierne på sykehuset var derimot svært fornøyde med at de ikke lenger trengte å ringe for å informere om aktuelle medisiner fordi disse opplysningene allerede skulle være sendt elektronisk. Det er vanskelig å vite årsaken til at sykepleierne i kommunen utfører dobbeltkontroll med en supplerende telefonsamtale hver gang for å bekrefte pasientens medisiner. Årsaken kan være at sykepleierne har opplevd at forskjellige skjemaer ikke stemmer overens. Kanskje har de dårlige erfaringer fra tidligere eller har opplevd situasjoner hvor feil i pasientens medisiner har truet pasientsikkerheten.

Til tross for at sykepleierne var fornøyde med meldingsfunksjonen, var det lettere å bruke telefon ved enkle henvendelser fordi det kan virke mer effektivt. De som svarer på telefonoppringingene, blir kanskje avbrutt eller opplever det som ekstraarbeid å svare på spørsmål om pasientens medisiner i og med at den informasjonen allerede skal være sendt elektronisk.

\section{Synlige helsetjenester}

Sammen med lovpålagt dokumentasjonsplikt (8) er dokumentasjon også en måte å videreutvikle helsetjenesten på ved at den synliggjør helsetjenestene en pasient får $(9,10)$. Når kommunikasjonen foregår elektronisk (2), synliggjør den en informasjonsutveksling som går på tvers av helsetjenestenivåer.

Telefonsamtalene kan bli dokumentert i den elektroniske pasientjournalen som en del av kommunikasjonen.

Likevel synliggjøres ikke den dokumenterte telefonsamtalen godt nok i og med at det i dag er forskjellige dokumentasjonsprogrammer i spesialist- og kommunehelsetjenesten (11). Det ville vært mer urovekkende om disse supplerende telefonsamtalene ikke fant sted, da de i utgangspunktet ble foretatt for å innhente informasjon som var mangelfull.

\section{Ser leste meldinger}


Flere av sykepleierne påpekte en fin funksjon med systemet ved at det dukket opp et ikon når en ny melding kom, og at man kunne kvittere for å ha lest meldingen. En sykepleier mente derimot at kvitteringen var en svakhet ved systemet fordi de kunne åpne meldingen, lese den, men velge ikke å kvittere. Dermed ble det ikke synlig at meldingen var lest.

Kvalitet i helsetjenesten skal være preget av kontinuitet (12). Dersom noen utsetter å ta stilling til en ny melding, forskyves oppgavene over på neste sykepleier som kommer på vakt. Ideelt sett kunne sykepleieren kvittere for alle meldingene, for da vil neste som kommer på vakt, fort kunne sette seg inn i hva som har blitt gjort, og hvilken informasjon som har blitt formidlet mellom helsetjenestene.

\section{Tar tid å dokumentere}

Noen av informantene syntes at dokumentasjonen krevde mye tid i en hektisk arbeidshverdag, slik en sykepleier fra kommunen sier:

«Jeg synes ofte det kan bli et valg mellom å dokumentere godt om pasienten og det å gi et godt stell. Jeg har det derfor bedre med meg selv dersom jeg heller bruker tiden på å gi et godt stell.»

Samtidig sa også sykepleierne at de bruker mye tid på emeldinger, og at det kan gå på bekostning av pasientrettet arbeid. Telefonsamtaler kan kanskje føles som den enkleste måten å henvende seg på i den spesifikke situasjonen, spesielt med tanke på kortere liggetid og raskere pasientforløp.

Gjennom et behandlingsforløp der mange forskjellige sykepleiere har vært involvert og informasjon har blitt formidlet på tvers av helsetjenestenivåer, vil det bli lettere å følge opp tråden fra vakt til vakt dersom all kommunikasjon har blitt dokumentert. Slik dokumentasjon skjer ikke automatisk hvis informasjon utveksles over telefonen. Det kan virke som at systemet, slik det fremstår, ikke har tatt høyde for behovet for forløpende dokumentasjon. 
Når kommunikasjonen foregår som dokumentasjon etter definerte maler, føles det kanskje mer tidkrevende å kommunisere. Når sykepleiere prioriterer å bruke mer tid på pasienten, føler kanskje pasienten seg bedre ivaretatt, og sykepleieren får et bedre grunnlag for hva som må dokumenteres. For liten tid med pasienten kan forårsake færre observasjoner og dermed svekke dokumentasjonsgrunnlaget (10).

\section{Tidspunkt varierer}

Informantene mente at pasientoverføringene mellom spesialist- og kommunehelsetjenesten er hyppigere enn tidligere, altså at flere pasienter trenger oppfølging av kommunens pleie- og omsorgstjeneste. De største utfordringene var derfor å ha tilstrekkelig informasjon på plass før pasientene ble utskrevet fra sykehuset. God og riktig informasjon er essensielt fordi pasientene skrives ut tidligere enn før og dermed er dårligere ved utskrivning.

\section{三 «Omsorgsmeldingene bidro til å avklare når informasjon skulle formidles.»}

Å få epikrisen før pasienten overflyttes til kommunehelsetjenesten, bidrar til bedre kvalitet på sykepleien. I tillegg bidrar det til effektivitet fordi sykepleierne på et tidlig tidspunkt kan sette seg inn i pasientens situasjon og begynne å planlegge sykepleien. Tjenestene er dermed virkningsfulle, og ressursene utnyttes på en hensiktsmessig måte (12). Sykepleierne i kommunen hadde erfart at tidspunktet for når viktig informasjon og epikrisen ble sendt over til dem, kunne variere fra avdeling til avdeling.

Informantene opplevde at omsorgsmeldingene bidro til å avklare når informasjon skulle formidles. Lyngstad og medarbeidere hevder at omsorgsmeldingene bidro til bedre kommunikasjonsrutiner (16). Omsorgsmeldingene har altså ført til tydeligere føringer for når informasjon skal formidles. På den måten kan de bidra til bedre effektivitet i samhandlingen. 
Informantene fortalte at informasjonen kommunen mottar, må inneholde nødvendig og riktig informasjon, slik at de kan overta pasienten på en forsvarlig måte som ivaretar pasientsikkerheten. Flere fortalte derimot at epikrisen noen ganger manglet viktig informasjon om blant annet medisiner, pasientens tidligere sykdommer og aktuelle prosedyrer.

\section{Felles forståelse viktig}

Funn i studien viste at sykepleierne opplevde bedre samhandling dersom alle hadde en felles forståelse av hvilken informasjon den som mottar pasienten, hadde behov for. Gjensidig forståelse på tvers av helsetjenestenivå og god dokumentasjon av den nødvendige informasjonen den mottakende enheten trenger, er avgjørende for samarbeidet $(7,14,15)$. Det er avgjørende å formidle informasjon på en forståelig måte for å klare å samhandle (14).

Sykepleierne på sykehuset fortalte at det lettet arbeidet med utskrivningsrapporten dersom det hadde blitt skrevet utfyllende om pasienten underveis i pasientforløpet. Flere informanter fortalte at det er med på å øke pasientsikkerheten når kommunikasjonen blir dokumentert.

Ifølge Statens helsetilsyn er det behov for flest forbedringer i overføringen av informasjon fra sykehus til kommune (13). Det krever derfor god planlegging for hver enkelt sykepleier å ta seg tid til å dokumentere godt.

\section{Kontinuitet og kvalitet}

Det er en forutsetning å dokumentere planlagt gjennomført sykepleie for å kunne vurdere kvaliteten av sykepleiebehandlinger (10). Sykepleierne følte seg sikrere når all kommunikasjon på tvers av helsetjenestenivåene ble dokumentert. Disse funnene underbygges av forskning (14). Det øker pasientsikkerheten å følge det lovpålagte kravet om dokumentasjon (9). 
Samtidig bidrar dokumentasjonen til synliggjøring og kontinuitet og er en faktor som gir helsetjenestene kvalitet $(8,9,12)$. Som sykepleier er man dermed både med på å sikre kvalitet og pasientsikkerhet ved å dokumentere godt, men også til å bidra til effektiv samhandling ved å ha tilstrekkelig informasjon tilgjengelig når pasienten forflyttes mellom tjenestenivåer.

\section{三 «Sykepleierne følte seg sikrere når all kommunikasjon på tvers av helsetjenestenivåene ble dokumentert.»}

Kvalitet i sykepleieutøvelsen handler blant annet om å ivareta pasientsikkerheten ved å redusere feil og uheldige hendelser til et minimum (12). Det kan virke som at sykepleiere tilsynelatende er bevisste på hva som er god kvalitet og pasientsikkert. Informantene rapporterte at de ringer for å innhente den manglende informasjonen om pasienten hvis de er usikre på om de har riktig eller tilstrekkelig dokumentasjon.

Kvalitetsforbedring i helsetjenesten har de siste årene rettet seg mye mot å effektivisere organiseringen (13). Overordnede føringer om å skrive ut pasienter raskere fra sykehuset til kommunehelsetjenesten øker dermed kravet til hver enkelt sykepleier om å formidle informasjon effektivt. For å innhente informasjon om og grunnlag til hva som skal dokumenteres og videreformidles, arbeider sykepleierne etter sykepleieprosessen (10).

Dersom mottakende enhet har fått tilstrekkelig informasjon om i hvilken grad pasienten har behov for sykepleie og hvilket system pasienten er en del av, vil det bli mer effektivt å forflytte pasienter mellom tjenestenivåer.

\section{Ulik forståelse}

Det varierte hvor god opplæring sykepleierne hadde fått i bruk av systemet. Likevel opplevde alle informantene at de hadde god kjennskap til hvordan de skulle håndtere systemet. 
Sykepleierne fortalte at det var helt avgjørende for samarbeidet at alle forsto systemet, spesielt med tanke på hvordan systemet fungerer som en kommunikasjonskanal mellom helsetjenestene. To av sykepleierne i kommunen fortalte at de noen ganger hadde fått telefon fra sykepleierne på sykehuset som åpenbart ikke forsto hvordan systemet fungerte. De rapporterte at sykepleiere fra sykehuset ved noen anledninger hadde ringt direkte til avdelingen for å spørre om de hadde plass til å ta imot en pasient.

Sykepleierne i kommunene måtte forklare at de på sykehuset måtte kontakte en saksbehandler gjennom meldingssystemet. Tjenestene blir dermed lite samordnet (12). Dersom alle som er involvert i behandlingen av pasienten, har den nødvendige informasjonen om pasienten og behandlingsforløpet frem til nå, vil det være en viktig faktor som bidrar til effektivitet og kvalitet $\mathrm{i}$ samhandlingen.

Sykepleierne ved sykehuset visste ikke at de hadde forskjellig dokumentasjonsprogram fra sykepleierne i kommunen. Informantene sa at det hadde hendt at sykepleierne på sykehuset mente at sykepleierne i kommunen bare kunne slå opp en prosedyre i Extend Quality System (EQS), som er enn helhetlig løsning for kvalitets- og virksomhetsstyring ved St. Olavs hospital, noe sykepleierne i kommunene altså ikke har tilgang til. Alle var enige om at dersom man forsto systemet med omsorgsmeldinger, var det enklere å forstå når informasjonen skulle formidles. En av sykepleierne fortalte følgende:

«Tidsfrister for når en elektronisk melding skal sendes, gjør det mer kvalitetssikkert, og det bidrar til bedre avklaring både på sykehuset og i kommunen for når informasjonen skal være på plass.»

Det er viktig at hver enkelt sykepleier setter seg godt inn i meldingssystemet, slik at de er oppdatert på den faglige utviklingen $(14,17)$.

\section{Konklusjon}


På bakgrunn av empiri, forskning og litteratur har vi i denne studien forsøkt å finne svar på om elektroniske omsorgsmeldinger har bidratt til effektivitet og kvalitet $\mathrm{i}$ dokumentasjonen og samhandlingen mellom spesialist- og kommunehelsetjenesten.

Elektroniske omsorgsmeldinger ser ut til å bidra til økt effektivitet og kvalitet med bedre informasjonsflyt mellom helsetjenestenivåene. Det bidrar til høyere pasientsikkerhet, og det er lettere å følge opp pasienten fordi alt blir dokumentert. Likevel mente sykepleierne at den mest effektive måten å kommunisere på, var å innhente informasjon over telefonen.

Dersom optimal informasjonsflyt og enda bedre samhandling skal oppnås, må alle som er involvert i den enkelte pasientens behandlingsforløp, sette seg godt inn i systemet med omsorgsmeldinger og forstå hva den som overtar pasienten, har behov for av informasjon.

Det vil også være viktig at de som utvikler esamhandlingssystemer, hører på hvilke behov brukerne, i dette tilfellet sykepleierne, har for å lage et system som har høy nytteverdi. I fremtiden, med et felles pasientjournalsystem, vil det trolig bli lettere å innhente informasjon. Det kunne være spennende å undersøke hvordan samhandlingen påvirkes da.

Vi samlet inn data fra bare to avdelinger, og derfor er funnene sparsomme. Dermed kan vi ikke trekke noen generelle slutninger for hvordan dokumentasjonen og samhandlingen mellom spesialist- og kommunehelsetjenesten faktisk er. Funnene støttes likevel av annen litteratur og forskning og kan dermed være et godt bidrag og nyttig i et lokalt perspektiv.

\section{Referanser}

1. Norsk Helsenett, Slagsvold H og Petersen K. Program for meldingsutbredelse. Trondheim: Norsk Helsenett;

2012. Tilgjengelig fra:

https://www.nhn.no/media/1157/rapport-ommeldingsutbredelse-i-kommunehelsetjenesten.pdf (nedlastet 17.08.18). 
2. Forskrift 1. juli 2015 nr. 853 om IKT-standarder i

helse- og omsorgstjenesten. Oslo: Helse- og

omsorgsdepartementet; 2015. Tilgjengelig fra:

https://lovdata.no/dokument/SF/forskrift/2015-07-01-853

(nedlastet 16.08.2018).

3. Helsedirektoratet. Samhandlingsstatistikk 2013-14.

Oslo: Helsedirektoratet; 2015. Rapport IS-2245.

Tilgjengelig fra:

https://helsedirektoratet.no/Lists/Publikasjoner/Attachments/798/Samhandlingsstatistikk-

2013-2014-IS-2245.pdf (nedlastet 04.04.2017).

4. Jørgensen T, Christensen E, Linneberg A. Klinisk

forskningsmetode: en grundbog. 4. utg. København:

Munksgaard; 2016.

5. Dalland O. Metode og oppgaveskriving. 5. utg. Oslo:

Gyldendal Akademisk; 2012.

6. Malterud K. Kvalitative metoder i medisinsk forskning

- en innføring. 3. utg. Oslo: Universitetsforlaget; 2017.

7. Brattheim BJ, Hellesø R, Melby L. Elektronisk

meldingsutveksling ved utskrivning av pasienter fra

sykehus til kommune. Sykepleien Forskning.

2016;11(1)26-33. Tilgjengelig fra:

https://doi.org/10.4220/Sykepleienf.2016.56830 (nedlastet

16.08.2018).

8. Lov 2. juli $1999 \mathrm{nr} .64$ om helsepersonell m.v.

(helsepersonelloven). Oslo: Helse- og

omsorgsdepartementet; 1999. Tilgjengelig fra:

https://lovdata.no/dokument/NL/lov/1999-07-02-64?q-

lov\%20om\%20helsepersonell (nedlastet 16.08.2018).

9. Sandvand E, Vabo G. Dokumentasjon i sykepleien. En basisbok i faglig og juridisk forsvarlig dokumentasjon.

Kristiansand: Høyskoleforlaget; 2007.

10. Dahl K, Skaug EA. Kliniske vurderingsprosesser og dokumentasjon i sykepleie. I: Skaug EA, red.

Grunnleggende sykepleie, bind 2. Grunnleggende behov.

2. utg. Oslo: Gyldendal Akademisk; 2011. s. 16-60. 
11. Helse Midt-Norge. Helseplattformen. For pasientens helsetjeneste. Én journal for hele helsetjenesten i MidtNorge. Trondheim: Helse Midt-Norge; 2018. Tilgjengelig fra: https://helse-midt.no/vartoppdrag/prosjekter/ehelse/helseplattformen/nasjonaltoppdrag (nedlastet 17.08.18).

12. Sosial- og helsedirektoratet. ... og bedre skal det bli! Nasjonal strategi for kvalitetsforbedring i Sosial- og helsetjenesten. Til deg som leder og utøver. Oslo: Sosialog helsedirektoratet; 2005. Veileder IS-1162. Tilgjengelig fra:

https://helsedirektoratet.no/Lists/Publikasjoner/Attachments/233/Ogbedre-skal-det-bli-nasjonal-strategi-forkvalitetsforbedring-i-sosial-og-helsetjenesten-2005-2015IS-1162-bokmal.pdf (nedlastet 18.04.2017).

13. Helsetilsynet. Informasjonen var mangelfull og kom ofte for sent. Oppsummering av landsomfattende tilsyn i 2015 med samhandling om utskrivning av pasienter fra spesialisthelsetjenesten til kommunen. Oslo: Statens helsetilsyn; 2016. Tilgjengelig fra:

https://www.helsetilsynet.no/upload/Publikasjoner/rapporter2016/helsetilsynetrapport1_2016.pdf (nedlastet 13.02.2017).

14. La Rocca A, Hoholm, T. Coordination between primary and secondary care: the role of electronic messages and economic incentives. BMC Health Services Research. 2017;17(1)149.

15. Kihlgren A, Wimo A, Mamhidir AG. Older patients referred by community nurses to emergency departments a descriptive cross-sectional follow-up study in a Swedish context. Scandinavian Journal of Caring Sciences.

2014;28(1):97-103.

16. Lyngstad M, Grimsmo A, Hofoss D, Hellesø R. Home care nurses' experiences with using electronic messaging in their communication with general practitioners. Journal of Clinical Nursing. 2014;23(23-24):3424-33.

17. Arntzen E. En forutsigbar helsetjeneste. Kvalitet og orden i eget hus. 1. utg. Oslo: Gyldendal Akademisk; 2007. 
